\title{
Effect of Integrated Nitrogen Management on Macronutrient Content and Uptake of Rice Fallow Rabi Blackgram
}

\author{
M. Latha*, P. Ratna Prasad, P.R.K. Prasad, R. Lakshmipathy and V. Srinivasarao \\ Department of Soil Science \& Agril. Chemistry, Agricultural College, Bapatla, India \\ *Corresponding author
}

\section{A B S T R A C T}

\section{Keywords}

INM, Yield of blackgram, Nutrient content, Nutrient, Uptake by rice fallow rabi blackgram

\section{Article Info}

Accepted:

22 June 2020

Available Online:

10 July 2020
A field experiment was conducted on the residual effect of integrated nitrogen management on rice and rice fallow blackgram crop. The major nutrient content $(\mathrm{N}, \mathrm{P} \&$ $\mathrm{K})$ and uptake by blackgram crop was studied during rabi season. The experiment was conducted at College Farm, Agicultural College, Bapatla during the kharif and rabi seasons of two years 2015 and 2016. The treatments consists of $\mathrm{M}_{1}(100 \% \mathrm{RDN})$ and $\mathrm{M}_{2}$ includes $50 \% \mathrm{RDN}+25 \% \mathrm{~N}$ through $\mathrm{FYM}+25 \% \mathrm{~N}$ through neem cake + recommended dose of microbial consortium (Azospirillum + PSB @ 2.5 $\mathrm{kg} \mathrm{ha}^{-1}$ ). The main treatments were imposed during kharif seasons of both the years and their residual effect was studied during rabi season with blackgram rabi crop. During the immediate kharif, the experiment was laid out in a split plot design without disturbing the soil for succeeding rabi crops with the two treatments given to kharif rice as main plot treatments and each of these divided into five sub-plots. Popular cultivars of rice (BPT 5204) and blackgram (PU 31) were used for this study. The highest nitrogen content was obtained in seed of blackgram (3.12\%) during 2015-16 and 3.25\% during 2016-17 year. The highest nitrogen uptake was noticed in seed $95.03 \mathrm{~kg} \mathrm{ha}^{-1}$ during 2015-16 and $104.81 \mathrm{~kg} \mathrm{ha}^{-1}$ of blackgram during 2016-17 year. The overall highest phosphorus content was obtained in seed of $1.34 \%$ during 201516 and $1.25 \%$ during 2016-17 year. The overall highest phosphorus uptake was noticed in seed of $40.81 \mathrm{~kg} \mathrm{ha}^{-1}$ during 2015-16 and $40.31 \mathrm{~kg} \mathrm{ha}^{-1}$ in seed of blackgram during 201617 year while the highest potassium content was obtained at harvest stage of haulm of $0.52 \%, 0.60 \%$ during first and second years. The overall $20.78 \mathrm{~kg} \mathrm{ha}^{-1}$ and $20.67 \mathrm{~kg} \mathrm{ha}^{-1}$ of potassium uptakes were noticed in haulms of blackgram crop observed during 2015-16 and 2016-17 years respectively.

\section{Introduction}

In recent years there has been adverse effect of continuous and indiscriminate use of inorganic fertilizers on deterioration of soil structure, soil health and environment. Intensive cultivation, mono cropping, use of imbalanced fertilization accompanied by restricted use of organic manures and biofertilizers have made the soils not only deficient in the nutrients but also deteriorated the soil health resulting in decline of crop response to the recommended dose of fertilizers. The high cost of fertilizers and unstable crop production call for substituting part of the inorganic fertilizers by locally 
available organic sources like farmyard manure, neem cake in an integrated manner for sustainable production and to maintain soil health. Integrated nitrogen management involving conjunctive use of organic, inorganic and crop residues may improve the soil productivity and system productivity become sustainable. Boosting yield, reducing production cost and improving soil health are three interlinked components of the sustainability triangle. Therefore, combined use of chemical fertilizers, organic manures and bio fertilizers is essential.

Hence, the present experiment is formulated to find out the residual effect of integrated nitrogen management on rice and rice fallow rabi blackgram crop and influence on nutrient contents of blackgram.

\section{Materials and Methods}

A field experiment was conducted for two consecutive years (2015-16 \& 2016-17) on clayloam soils of Agricultural College Farm, Bapatla. The experiment was laid out in a two sample t-test for rice in kharif season with 2 treatments and replicated thrice. The treatments consists of $\mathrm{M}_{1} 100 \% \mathrm{RDN}, \mathrm{M}_{2}$ $(50 \% \mathrm{RDN}+25 \% \mathrm{~N}$ through FYM $+25 \% \mathrm{~N}$ Through neem cake + Azopsirillum + PSB @ $2.5 \mathrm{~kg} \mathrm{ha}^{-1}$ (INM). During the immediate kharif, the experiment was laid out in a split plot design without disturbing the soil for succeeding rabi crops with the two treatments given to kharif rice as main plot treatments and each of these divided into five sub-plots. The experiment was repeated in another field during kharif and rabi seasons. Popular cultivars of rice (BPT 5204) and blackgram (PU 31) were used for this study.

The soil was vertisol with bulk density (1.42 $\& 1.43)$, porosity (43.50 and $43.80 \%)$ and water holding capacity (45.10 \& 45.80\%), slightly alkaline in reaction, $(\mathrm{pH} 7.70$ and $7.50)$, two fields were non-saline in nature, cation exchange capacity (35.4 \& 37.2), medium range of organic carbon $(0.55$ and $0.50 \%$ ). Low nitrogen content (266 and 250 $\mathrm{kg} \mathrm{ha}^{-1}$ ), available phosphorus was (59 and 53 $\mathrm{kg} \mathrm{ha}^{-1}$ ) and available potassium (630 and 668 $\left.\mathrm{kg} \mathrm{ha}{ }^{-1}\right)$.The initial soil analysis data is presented in table 1 . The present investigation was undertaken during 2015-16 and 2016-17 of consecutive years.

The nutrients were applied through the fertilizers like urea, single super phosphate, muriate of potash. The farm yard manure and neem cake was applied at seven days before transplanting of rice on dry weight basis as per the treatment. The bacterial inoculants applied at the time of sowing as per recommended dosage (Azospirillum + PSB @ $5.0 \mathrm{~kg} \mathrm{ha}^{-1}$ ).

The recommended fertilizer doses were applied as 120-40-40, 20-50-0 kg N, $\mathrm{P}_{2} \mathrm{O}_{5}$ and $\mathrm{K}_{2} \mathrm{O}$ ha $^{-1}$ to rice and blackgram crops. The soil samples were analysed as per standard procedures for soil physical and physicochemical properties. Soil texture by Piper, 1966, bulk density by Dastane, 1967, water holding capacity by Sankaram, 1966, soil reaction and EC by Jackson, 1973, CEC by Bower et al., 1952 and organic carbon by Walkley and Black, 1934 . The data obtained during kharif 2015-16 and 2016-17 were analysed statistically using two sample t-test analysis of variance (Panse and Sukhatme, 2000). The t-test value calculated for 12 replications and t-test value was 2.07. If the t-test value was $>2.07$, it was significant, while $<2.07$ includes nonsignificant. Whereas the data obtained during rabi 2015-16 and 2016-17 were analyzed statistically by following split plot design as suggested by Gomez and Gomez (1984). Wherever, the treatment differences were found significant, critical differences were worked out at five per cent probability level and furnished along with mean values of the parameter concerned in tables. Nonsignificant treatmental differences were 
denoted by "NS".

\section{Collection and processing of plant samples}

Blackgram plant samples were collected from five random sites in each treatment at different growth stages and sent for laboratory for further analysis. The samples were first dried in shade and then in hot air oven at $65^{\circ} \mathrm{C}$. The plant samples were ground in willey mill and stored in labeled brown paper bags for analysis. The grain samples were also processed and stored in similar fashion.

\section{Nitrogen}

Nitrogen content in plant samples was determined by micro Kjeldahl method (Piper, 1966).

\section{Preparation of di-acid mixture}

Di-acid extract was prepared as per the method outlined by Jackson (1973). It was carried out using a 9:4 mixture of $\mathrm{HNO}_{3}$ : $\mathrm{HClO}_{4}$. The pre-digestion of sample was done by using $10 \mathrm{ml}$ of $\mathrm{HNO}_{3} \mathrm{~g}^{-1}$ sample. This diacid extract was used to determine $\mathrm{P}$ and $\mathrm{K}$ contents in the plant and grain samples.

\section{Phosphorus}

It was determined spectrophotometrically by vanadomolybdate phosphoric acid yellow color method as described by Jackson (1973) from di-acid extract.

\section{Potassium}

It was estimated from di-acid extract by using flame photometer (Jackson, 1973).

\section{Nutrient uptake}

From the chemical analytical data, uptake of the each nutrient was calculated as shown below.

Nutrient uptake $\left(\mathrm{kg} \mathrm{ha}^{\mathbf{- 1}}\right)=$

Nutrient content $(\%)$ x dry matter in $\mathrm{kg} \mathrm{ha}^{-1}$

\section{0}

\section{Results and Discussion}

\section{Seed yield of Blackgram}

Seed yields of blackgram were presented in table 2 and depicted in figure 1. Significantly highest seed yield was obtained in residual effect of $\mathrm{M}_{2}$ treatment with values of 1118 and $1210 \mathrm{~kg} \mathrm{ha}^{-1}$ in the year 2015-16 and 2016-17, respectively. These yields were higher by $21.9 \%$ and $10.40 \%$ over $\mathrm{M}_{1}$ during first and second years, respectively, which indicated the residual effect of INM treatment $\left(\mathrm{M}_{2}\right)$ imposed in rice during kharif.

Similar results were obtained by Gajendrasingh et al. (2016) who reported that residual effect of INM had showed the highest seed yield in blackgram compared to inorganics alone. Shashikumar et al. (2013) had also stated that highest yields were obtained with organics in conjunction with inorganics. Growth regulators combinedly affect the grain yield of blackgram crop. Geetha and Velayutham, (2016) also supported that the fertilizer application methods followed in the preceding rice crop did exert significant variation in the grain yield of succeeding blackgram crop and the percent of yield increase due to fertilizer application to blackgram was $12 \%$ over application of the recommended dose of fertilizer to preceding rice crop. The increase in yield might be due to enhancement in growth and yield parameters as well as uptake of nutrients by crop. Obviously, the cumulative effects of these parameters might have contributed to increased grain yield 
potential of the crop. Anulavanya and Ganapathy, (2010) stated that the maximum seed yield was recorded with $2 \%$ DAP + biofertilizers. The rhizobium inoculation formed good nodulation and increased blackgram showing effective symbiosis which might have left appreciable amount of $\mathrm{N}$ to increase yield. Phosphobacteria application made the insoluble phosphates present in the soil into soluble forms by secreting organic acids resulting in effective solubilization and utilization of phosphorus.

Devaraju and Senthivel (2018) concluded that the grain yield was increased with application of pulse wonder @ 5kg/ha (organics) gave significantly highest grain yield than other treatments. The increase in yield might be due to enhanced yield attributes like number of pods plant ${ }^{-1}$, number of seed pod $^{-1}$ and increased uptake of nutrients by blackgram by effective translocation of nutrients from sink to reproductive area of crop. Selvakumar et al. (2009) stated that the yield of blackgram increased with biofertilizers (dual inoculation of rhizobium with phosphobacteria). It was evident that INM treatment increased plant height, leaf number and leaf area contributing to increased yield. Senthivalavan and Ravichandran (2016) reported that residual effect of integrated plant nutrient supply NPK ha $^{-1}$ along with $12.5 \mathrm{t} \mathrm{ha}^{-1}$ FYM and biofertilizers viz., Azospirillum and PSB as soil treatment obtained increased seed yields. This might be due to better availability of $\mathrm{P}$ to blackgram during rabi season when applied to preceding rice crop in kharif season.

\section{Haulm yield of blackgram}

To evaluate the residual effect of INM practice imposed in kharif rice, the rabi yields of blackgram haulm yield were recorded in table 2 and depicted in figure 1. The haulm yields of INM $\left(\mathrm{M}_{2}\right)$ treatment were higher by $91(6.33 \%)$ and $113 \mathrm{~kg} \mathrm{ha}^{-1}(7.52 \%)$ over $\mathrm{M}_{1}$ (only inorganics). The residual effect of INM treatment was confirmed with the above significant increase in haulm yield.

The application of organics along with $50 \%$ RDN showed the increments in yield of haulm yields. Similar type of results were found with Gajendrasingh et al. (2016) and the increase of yield in organic manure treatment was due to the higher photosynthetic activity in blackgram plant leading to the better supply of carbohydrates resulting in more number of branches and dry matter. Increase in straw yield might be due to the cumulative influence of improvement in vegetative growth of crop through the atmospherically nitrogen fixed in the root nodules Ghosh and Joseph (2008).

Senthivalavan and Ravichandran (2016) reported that integrated plant nutrient supply NPK along with FYM and biofertilizers viz., Azospirillum and PSB as soil treatment obtained increased seed and haulm yields. This might be due to better availability of phosphorus to blackgram during rabi season when applied to preceding rice crop in kharif season. The superiority of residual effect of FYM and biofertilizers through efficient utilization of mineralized $\mathrm{N}$ and $\mathrm{Zn}$ from FYM along with atmospheric $\mathrm{N}$ fixed by the crop itself (by increasing the activity of nodule bacteria would have increased the availability of $\mathrm{N}$ throughout the growth period and thereby increased the assimilation of photosynthates which in turn better source and sink relationship led to better performance of rice fallow blackgram crop.

\section{Harvest index}

Significantly higher harvest index was obtained with residual effect of INM treatment in both the years. The conversion of biomass into reproductive organs of yield attributing character was revealed in INM treatment. Harvest index value was recorded in $\mathrm{M}_{1}(39.85 \%)$ over than that of $\mathrm{M}_{2}(42.25 \%)$ 
during 2015-16 year and 42.18 to $42.83 \%$ during the year 2016-17.

\section{Nutrient content and uptake}

\section{Nitrogen}

The experimental results pertaining to nitrogen content at different growth stages of blackgram crop are presented in table 3. Data indicated that there was significant residual effect of $\mathrm{M}_{2}$ (INM) treatment over $100 \%$ RDN on nitrogen content of blackgram. At all the growth stages of blackgram the $\mathrm{N}$ content was significantly higher with $\mathrm{M}_{2}$ treatment than $\mathrm{M}_{1}$ during both the years of study.

The nitrogen content was gradually decreased with the age of the crop i.e from vegetative stage to flowering stage. The highest nitrogen content was obtained within seed of $3.12 \%$ during 2015-16 and 3.25\% during 2016-17 year. This was coincided with the results of Gajendrasingh et al., (2016) and due to the increased root development and more nutrient availability, resulting in better absorption and utilization of all plant nutrients, thus resulting in more nitrogen content in seed. Rhizobium inoculation increased the root nodulation through better root development and more nutrient availability, resulting in better absorption and utilization of all plant nutrients, thus resulting in more nitrogen content in seed. Similar type of results was reported by Singh and Pareek, (2003).

The experimental results pertaining to nitrogen uptake at different growth stages of crop are presented in table 4. Data indicated that there was significant influence of the residual effect of $\mathrm{M}_{2}$ treatment over $100 \%$ $\operatorname{RDN}\left(\mathrm{M}_{1}\right)$. The significant increase was noticed in nutrient uptake during two years of study.
The nitrogen uptake was also increased from vegetative stage to flowering stage. The highest nitrogen uptake was noticed in seed $95.03 \mathrm{~kg} \mathrm{ha}^{-1}$ during 2015-16 and $104.81 \mathrm{~kg}$ $\mathrm{ha}^{-1}$ of blackgram during 2016-17 year. Similar type of range of nitrogen uptakes by blackgram crop was happened with Gajendrasingh et al. (2016) and Senthilvalavan and Ravichandran, (2016).

\section{Phosphorus}

The experimental results pertaining to phosphorus content at different growth stages of blackgram are presented in table 3. Data indicated that there was significant influence of the residual effect of $\mathrm{M}_{2}$ treatment over $100 \%$ RDN at all the growth stages in both years of study. Mir et al. (2013) stated that phosphorus solubilizers increased the availability thereby improved phosphorus and plant and uptake of nutrient manifested in increased concentration.

The phosphorus content was gradually decreased with the age of the crop i.e from vegetative stage to flowering stage. The overall highest phosphorus content was obtained in seed of $1.34 \%$ during 2015-16 and $1.25 \%$ during 2016-17 year. This was coincided with those of Gajendrasingh et al. (2016).

The higher phosphorus content in seed was due to increased better root development and more nutrient availability, resulting in better absorption and utilization of all plant nutrients, thus resulting in more phosphorus content in seed.

The experimental results pertaining to phosphorus uptake at different growth stages of crop are presented in table 4 . 
Table.1 Initial properties of the experimental soil

\begin{tabular}{|c|c|c|c|}
\hline Particulars & 2015-16 & 2016-17 & Class/ Group \\
\hline \multicolumn{4}{|l|}{ I. Physical properties } \\
\hline \multicolumn{4}{|l|}{ Mechanical composition } \\
\hline 1. Sand $(\%)$ & 42 & 40 & \\
\hline 2. Silt (\%) & 20 & 21 & \\
\hline 3. Clay (\%) & & & \\
\hline Textural class & Clay loam & Clay loam & Clay loam \\
\hline Bulk density $\left(\mathrm{Mg} \mathrm{m}^{-3}\right)$ & 1.44 & 1.43 & Normal \\
\hline Porosity $(\%)$ & 43.50 & 43.80 & Normal \\
\hline Water holding capacity (\%) & 45.10 & 45.80 & Normal \\
\hline \multicolumn{4}{|l|}{ II. Physico-chemical properties } \\
\hline pH (1:2.5) & 7.70 & 7.50 & $\begin{array}{l}\text { Neutral to slightly } \\
\text { alkaline in nature }\end{array}$ \\
\hline$E C\left(d S m^{-1}\right)$ & 0.26 & 0.31 & Non-saline \\
\hline $\begin{array}{l}\text { Cation exchange capacity } \\
\left(\mathbf{c m o l}(\mathrm{p}+) \mathrm{kg}^{-1}\right)\end{array}$ & 35.4 & 37.2 & Normal \\
\hline Organic carbon (\%) & 0.55 & 0.50 & medium \\
\hline \multicolumn{4}{|l|}{ III. Available nutrients } \\
\hline $\mathbf{N}\left(\mathrm{kg} \mathrm{ha}^{-1}\right)$ & 266 & 250 & Low \\
\hline $\mathrm{P}_{2} \mathrm{O}_{5}\left(\mathrm{~kg} \mathrm{ha}^{-1}\right)$ & 59 & 53 & High \\
\hline $\mathrm{K}_{2} \mathrm{O}\left(\mathrm{kg} \mathrm{ha}^{-1}\right)$ & 630 & 668 & Very high \\
\hline Particulars & 2015-16 & 2016-17 & Class/ Group \\
\hline \multicolumn{4}{|l|}{ IV. Secondary nutrients } \\
\hline Exchangeable Ca (cmol (p+) kg-1) & 23.39 & 24.07 & Normal \\
\hline Exchangeable $\mathrm{Mg}\left(\mathrm{cmol}(\mathrm{p}+) \mathrm{kg}^{-1}\right)$ & 5.80 & 5.70 & Normal \\
\hline $\mathrm{SO}_{4}^{-2}-$ Sulphur $\left(\mathrm{mg} \mathrm{kg}^{-1}\right)$ & 15.00 & 15.50 & Normal \\
\hline \multicolumn{4}{|c|}{ V. Available micro nutrients $\left(\mathrm{mg} \mathrm{kg}^{-1}\right)$} \\
\hline Iron & 27.50 & 25.00 & Sufficient \\
\hline Manganese & 5.50 & 4.90 & Sufficient \\
\hline Zinc & 2.55 & 2.65 & Sufficient \\
\hline Copper & 0.59 & 0.65 & Sufficient \\
\hline \multicolumn{4}{|l|}{ VI. Biological properties } \\
\hline $\begin{array}{l}\text { Dehydrogenase activity } \\
\left(\mu \mathrm{g} \mathrm{TPF}^{-1} 24 \mathrm{~h}^{-1}\right)\end{array}$ & 49.14 & 39.15 & Normal \\
\hline \multicolumn{4}{|l|}{ Microbial populations } \\
\hline $\begin{array}{l}\text { Bacteria count } \\
\left(10^{5} \times \text { cfu }^{-1} \text { soil }\right)\end{array}$ & 20.0 & 25.0 & Normal \\
\hline Fungi $\left(10^{3} \times\right.$ cfu $g^{-1}$ soil $)$ & 10.0 & 8.0 & Normal \\
\hline $\begin{array}{l}\text { Actinomycetes } \\
\left(10^{3} \times \text { cfu }^{-1} \text { soil }\right)\end{array}$ & 15.0 & 15.0 & Normal \\
\hline
\end{tabular}


Table.2 Effect of Integrated Nitrogen Management on yield attributes and yield of rice fallow rabi blackgram

\begin{tabular}{|c|c|c|c|c|c|c|c|c|}
\hline \multirow[t]{2}{*}{ Treatment } & \multicolumn{4}{|c|}{ 2015-16 } & \multicolumn{4}{|c|}{ 2016-17 } \\
\hline & $\begin{array}{c}100 \text { seed } \\
\text { weight }(g)\end{array}$ & $\begin{array}{c}\text { Seed } \\
\text { yield } \\
\left(\mathrm{kg} \mathrm{ha}^{-1}\right)\end{array}$ & $\begin{array}{l}\text { Haulm } \\
\text { yield } \\
\left(\mathrm{kg} \mathrm{ha}^{-1}\right)\end{array}$ & $\begin{array}{c}\text { Harvest } \\
\text { Index } \\
(\%)\end{array}$ & $\begin{array}{c}100 \text { seed } \\
\text { weight }(g)\end{array}$ & $\begin{array}{c}\text { Seed } \\
\text { yield } \\
\left(\mathrm{kg} \mathrm{ha}^{-1}\right)\end{array}$ & $\begin{array}{l}\text { Haulm } \\
\text { yield } \\
\left(\mathrm{kg} \mathrm{ha}^{-1}\right)\end{array}$ & $\begin{array}{c}\text { Harvest } \\
\text { Index } \\
(\%)\end{array}$ \\
\hline $\mathrm{M}_{1}: 100 \% \mathrm{RDN}$ & 3.98 & 917 & 1437 & 38.95 & 4.55 & 1096 & 1502 & 42.18 \\
\hline $\begin{aligned} \mathrm{M}_{2}: & \mathbf{5 0 \%} \mathrm{RDN}+\mathbf{2 5 \%} \mathrm{N}-\mathrm{FYM}+ \\
& \mathbf{2 5 \%} \mathrm{N}-\text { neem cake }+ \\
& \text { bacterial consortium }\end{aligned}$ & 4.17 & 1118 & 1528 & 42.25 & 4.91 & 1210 & 1615 & 42.83 \\
\hline t-value & 9.76 & 14.10 & 5.15 & 2.15 & 8.11 & 4.75 & 12.85 & 2.07 \\
\hline
\end{tabular}


Table.3 Effect of Integrated Nitrogen Management on N, P and K contents in rice fallow rabi blackgram

\begin{tabular}{|c|c|c|c|c|c|c|c|c|}
\hline \multirow[t]{2}{*}{ Treatment } & \multicolumn{4}{|c|}{ 2015-16 } & \multicolumn{4}{|c|}{ 2016-17 } \\
\hline & Vegetative & Flowering & Haulm & Seed & Vegetative & Flowering & Haulm & Seed \\
\hline \multicolumn{9}{|l|}{ Nitrogen $(\%)$} \\
\hline $\mathrm{M}_{1}: 100 \% \mathrm{RDN}$ & 1.56 & 1.36 & 0.44 & 3.05 & 1.58 & 1.48 & 0.54 & 3.11 \\
\hline $\begin{aligned} \mathrm{M}_{2}: & \mathbf{5 0} \% \mathrm{RDN}+25 \% \mathrm{~N}-\mathrm{FYM}+\mathbf{2 5 \%} \\
& \mathrm{N} \text { - neem cake + bacterial } \\
& \text { consortium }\end{aligned}$ & 1.63 & 1.46 & 0.62 & 3.12 & 1.86 & 1.59 & 0.66 & 3.25 \\
\hline t - value & 3.60 & 2.51 & 4.56 & 5.92 & 3.69 & 2.11 & 2.15 & 2.11 \\
\hline \multicolumn{9}{|l|}{ Phosphorus (\%) } \\
\hline $\mathrm{M}_{1}: 100 \% \mathrm{RDN}$ & 0.33 & 0.30 & 0.28 & 1.08 & 0.45 & 0.40 & 0.32 & 0.99 \\
\hline $\begin{aligned} \mathrm{M}_{2}: & \mathbf{5 0} \% \mathrm{RDN}+\mathbf{2 5} \% \mathrm{~N}-\mathrm{FYM}+\mathbf{2 5 \%} \\
& \mathrm{N} \text { - neem cake + bacterial } \\
& \text { consortium }\end{aligned}$ & 0.38 & 0.35 & 0.33 & 1.34 & 0.64 & 0.60 & 0.43 & 1.25 \\
\hline t - value & 2.34 & 2.19 & 2.42 & 2.52 & 4.79 & 3.77 & 2.27 & 2.16 \\
\hline \multicolumn{9}{|l|}{ Potassium(\%) } \\
\hline $\mathrm{M}_{1}: 100 \% \mathrm{RDN}$ & 1.24 & 1.18 & 1.04 & 0.41 & 1.36 & 1.26 & 1.02 & 0.55 \\
\hline $\begin{aligned} & \mathrm{M}_{2}: \mathbf{5 0} \% \mathrm{RDN}+\mathbf{2 5} \% \mathrm{~N}-\mathrm{FYM}+\mathbf{2 5 \%} \\
& \mathrm{N}-\text { neem cake }+ \text { bacterial } \\
& \text { consortium }\end{aligned}$ & 1.39 & 1.29 & 1.36 & 0.52 & 1.48 & 1.37 & 1.28 & 0.60 \\
\hline t - value & 2.25 & 2.17 & 3.34 & 2.13 & 2.56 & 2.20 & 2.17 & 2.17 \\
\hline
\end{tabular}


Table.4 Effect of Integrated Nitrogen Management on macronutrient uptake by rice fallow rabi blackgram

\begin{tabular}{|c|c|c|c|c|c|c|c|c|}
\hline \multirow[t]{2}{*}{ Treatment } & \multicolumn{4}{|c|}{ 2015-16 } & \multicolumn{4}{|c|}{ 2016-17 } \\
\hline & Vegetative & Flowering & Haulm & Seed & Vegetative & Flowering & Haulm & Seed \\
\hline \multicolumn{9}{|l|}{ Nitrogen $\left(\mathrm{kg} \mathrm{ha}^{-1}\right)$} \\
\hline $\mathrm{M}_{1}: 100 \% \mathrm{RDN}$ & 1.43 & 11.68 & 6.32 & 27.9 & 1.40 & 12.81 & 8.11 & 34.85 \\
\hline $\begin{array}{l}\mathrm{M}_{2}: \mathbf{5 0 \%} \quad \mathrm{RDN}+\mathbf{2 5 \%} \mathrm{N}-\mathrm{FYM}+ \\
\mathbf{2 5 \%} \mathrm{N}-\text { neem cake + bacterial } \\
\text { consortium }\end{array}$ & 2.44 & 13.72 & 4.27 & 34.8 & 3.06 & 16.02 & 10.65 & 39.32 \\
\hline $\mathrm{t}$ - value & 2.15 & 7.07 & 6.26 & 18.14 & 2.35 & 2.93 & 3.47 & 3.77 \\
\hline \multicolumn{9}{|l|}{ Phosphorus (kg ha ${ }^{-1}$ ) } \\
\hline $\mathrm{M}_{1}: 100 \% \mathrm{RDN}$ & 0.30 & 2.57 & 4.02 & 9.90 & 0.40 & 3.46 & 4.80 & 10.85 \\
\hline $\begin{array}{l}\mathrm{M}_{2}: 50 \% \quad \mathrm{RDN}+25 \% \mathrm{~N}-\mathrm{FYM}+ \\
25 \% \mathrm{~N}-\text { neem cake + bacterial } \\
\text { consortium }\end{array}$ & 0.57 & 3.29 & 5.04 & 14.98 & 1.05 & 3.65 & 6.94 & 15.12 \\
\hline $\mathrm{t}$ - value & 2.17 & 11.63 & 3.30 & 4.41 & 2.92 & 9.47 & 2.93 & 3.06 \\
\hline \multicolumn{9}{|l|}{ Potassium $\left(\mathrm{kg} \mathrm{ha}^{-1}\right)$} \\
\hline $\mathrm{M}_{1}: 100 \% \mathrm{RDN}$ & 1.14 & 10.13 & 14.9 & 3.75 & 1.21 & 12.64 & 15.32 & 4.82 \\
\hline $\begin{array}{l}\mathrm{M}_{2}: \mathbf{5 0 \%} \mathrm{RDN}+\mathbf{2 5 \%} \mathrm{N}-\mathrm{FYM}+ \\
25 \% \mathrm{~N}-\text { neem cake + bacterial } \\
\text { consortium }\end{array}$ & 2.08 & 12.12 & 20.78 & 5.81 & 2.44 & 16.09 & 20.67 & 6.77 \\
\hline t - value & 2.45 & 3.53 & 4.54 & 5.17 & 2.79 & 9.43 & 3.45 & 3.34 \\
\hline
\end{tabular}


Fig.1 Effect of Integrated Nitrogen Management on yield of rice fallow rabi blackgram

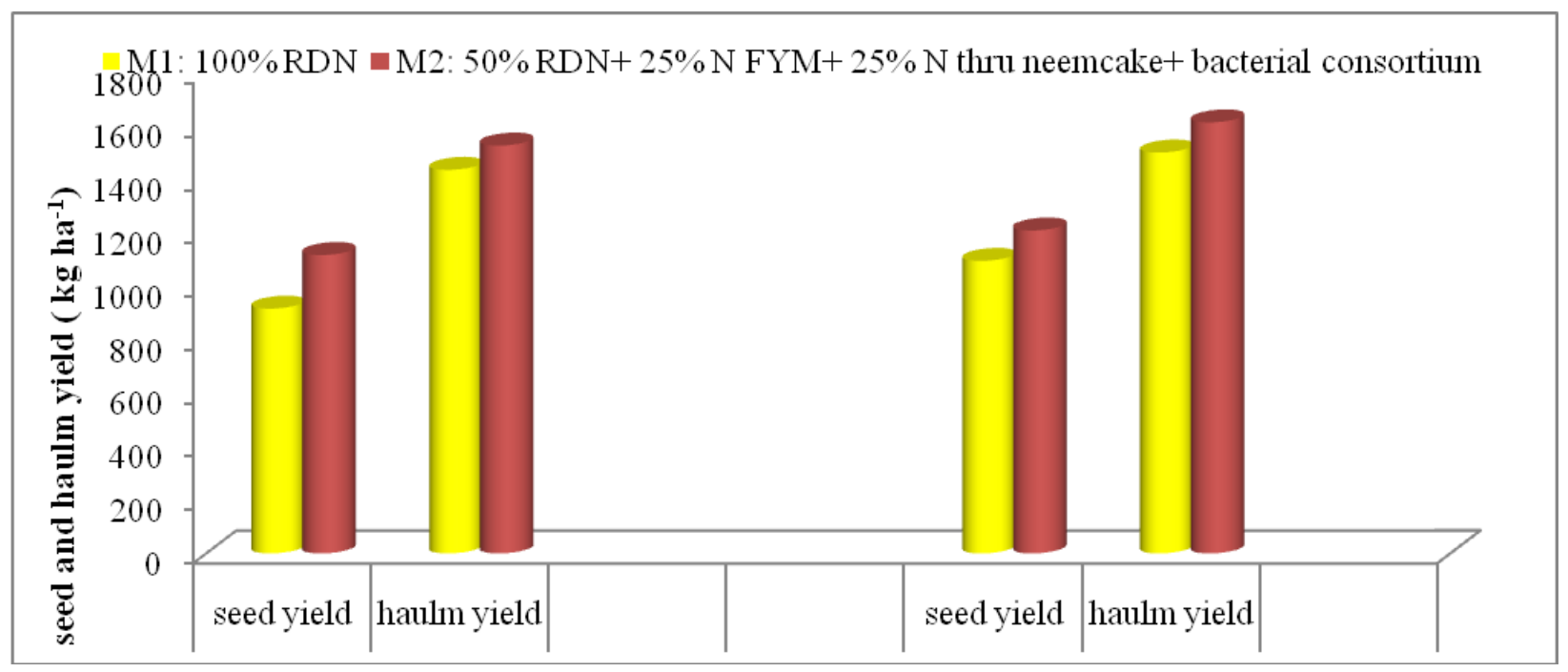

The phosphorus uptake also increased from vegetative stage to flowering stage. Data indicated that there was significant increase of the residual effect of $\mathrm{M}_{2}$ treatment over 100\% RDN had given the significantly higher phosphorus uptake. The significant increase was noticed in nutrient uptake during two years of study. The overall highest phosphorus uptake was noticed in seed of $40.81 \mathrm{~kg} \mathrm{ha}{ }^{-1}$ during $2015-16$ and $40.31 \mathrm{~kg}$ $\mathrm{ha}^{-1}$ in seed of blackgram during 2016-17 year. Similar type of range of phosphorus uptake observed by blackgram crop was noticed with Harishkumarmehta et al (2015).

\section{Potassium}

Potassium content at different growth stages of crop were presented in table 3. Potassium content was gradually decreased with the age of the crop i.e from vegetative stage to flowering stage. The highest potassium content was obtained at harvest stage of haulm of $0.52 \%$ during first and $0.60 \%$ during second year (Mir et al., 2013).

There was significant residual effect of $\mathrm{M}_{2}$ treatment over $100 \%$ RDN. Irrespective of growth stage the highest potassium content was obtained with residual effect of $\mathrm{M}_{2}$ over $\mathrm{M}_{1}$ (only inorganics). Similar type of results was quoted by Harishkumarmehta et al., (2015). There was residual effect of $\mathrm{M}_{2}$ treatment over $100 \%$ RDN. Similar type of potassium uptakes were stated by Gajendrasingh et al. (2016).

The potassium uptake was also increased from vegetative stage to flowering stage as it is a product of content and dry matter. The significant increase was noticed in nutrient uptake during two years of study. The overall highest nutrient potassium uptake was noticed in haulm of $20.78 \mathrm{~kg} \mathrm{ha}^{-1}$ during 2015-16 and $20.67 \mathrm{~kg} \mathrm{ha}^{-1}$ in haulm of blackgram during 2016-17 year.

The highest nutrient uptakes of blackgram were obtained due to higher dry matter production and increased availability of nutrients from the INM might have enhanced the $\mathrm{K}$ uptake. These results were in conformity with the findings of Geetha and Velayutham (2016).

In conclusion, application of integrated nitrogen management improved the macronutrient content and uptake of rice fallow rabi blackgram with the implication of 
$\mathrm{M}_{2}\{50 \% \mathrm{RDN}+25 \% \mathrm{~N}$ through $\mathrm{FYM}+$ $25 \% \mathrm{~N}$ through neem cake + recommended dose of microbial consortium (Azospirillum + PSB @ 2.5kg ha ${ }^{-1}$ \} during kharif season. Nitrogen, Phosphorus and potassium uptakes in seed were increased $24.7 \%, 51 \%$ and $69 \%$ respectively during first year and in second year $13.9 \%, 48 \%$ and $40 \%$ increments were noticed in seed uptakes of $\mathrm{N}, \mathrm{P}$ and $\mathrm{K}$ respectively. This conclusion was based on two years study the evaluation and assessment need long-term experimentation on different agro-climatic conditions and locations.

\section{References}

Anu Lavanya, G and Ganapathy, M. 2010. Yield maximization of blackgram in rice fallow blackgram through organic sources of nutrient management practices in Cauvery deltaic areas. Legume Research, 33(4):291-294.

Bower, C.A., Reitemeier, R.F and Fireman, M. 1952. Exchangeable cations analysis of saline and alkali soils. Soil Science, 73: 251-261.

Dastane, N.G., 1967. A Practical Manual for water use research, Navabharat, Prakashan Publication, Poona (India), 120.

Devaraju, B and Senthivel, T. 2018. Effect of foliar application of different sources of nutrients on growth and yield of blackgram under irrigated conditions. International Journal of Current Microbiology and applied Sciences. 7(10): 3105-3109.

Gajendra Singh, Pushkar Choudhary, Bharat Lal Meena, Rajveer Singh Rawat and Bhanwar lal Jat, 2016. Integrated nutrient management in Blackgram under rainfed condition. International Journal of Recent Scientific Research, 7(10): 13875-13894.

Geetha, P and Velayutham, A. 2016. Yield attributes, yield and uptake of nutrients as influenced by basal and foliar application of nutrients on rice fallow blackgram, Indian Journal of Agricultural Research., 50(2): 122-125.

Ghosh, M. K and Joseph, S. A. 2008. Influence of biofertilizers, foliar application of DAP and sulphur sources on yield and yield attributes of summer greengram. Legume Research, 31(3): 232-233.

Gomez, K. A and Gomez, A.A. 1984. Randomized Block Design in Statistical Procedure for Agricultural Research. Published by a Wiley Inter Science, USA: 621-635.

Harish Kumar Mehta, R., Subhash Reddy, P., Jayamma and Naveen Kumar, R. 2015. Influence of biofertilizers, vermicompost and chemical fertilizers on growth, nodulation, nutrient uptake, seed yield and economics of blackgram. International Journal of applied biology and Pharmaceutical Technology. 6(3): 249-251.

Mir, A. H., Lal, S. B., Salmani, M., Abid, M and Khan, I. 2013. Growth, yield and nutrient content of blackgram as influenced by levels of phosphorus, sulphur and phosphorus solubilizing bacteria. SAARC. Journal, 11(1): 1-6.

Panse, V. G and Sukhatme, P. V. 2000. Statistical methods for Agricultural workers. Published by ICAR, New Delhi.

Piper, C. S. 1966. Soil and plant analysis. Hans Publishers, Bombay: 368.

Sankaram, A. 1966. A laboratory manual for agricultural chemistry. Asia publishing House. Bombay. 41-149.

Selvakumar, G. Lenin, M., Thamizhiniyan, P and Ravimycin. 2009. Response of biofertilizers on the growth and yield of blackgram. Recent research in science and Technology,1(4): 169-175.

Senthilvalavan, $\mathrm{P}$ and Ravichandran, $\mathrm{M}$. 
2016. Residual effect of nutrient management practices on the yield, NPK uptake and profitability of rice fallow blackgram. Asian Journal of Science and Technology, 7(1): 23052310.

Shashikumar, Basavarajappa, Salikinkkop, S. R., Majunatha Hebbar, Basavarajappa, M. P and Patil, H. Y. 2013. Effect of growth regulator, organic and inorganic foliar nutrition on the growth and yield of blackgram under rainfed condition. Karnataka Journal of Agricultural Sciences, 26(2): 311-313.
Singh, B and Pareek R G, 2003. Studies on phosphorus and nbio-inoculants on biological nitrogen fixation, concentration, uptake, quality and productivity of mung bean. Annals of Agriculture New Series. 24(3): 537541.

Walkley, A. Black, A. 1934. An Examination of degtjareff, method for determining soil organic matter and a proposed modification of the chromic acid titration method. Soil Science. 37: 2938.

\section{How to cite this article:}

Latha, M., P. Ratna Prasad, P.R.K. Prasad, R. Lakshmipathy and Srinivasarao, V. 2020. Effect of Integrated Nitrogen Management on Macronutrient Content and Uptake of Rice Fallow Rabi Blackgram. Int.J.Curr.Microbiol.App.Sci. 9(07): 3458-3469. doi: https://doi.org/10.20546/ijcmas.2020.907.404 